\title{
Iodine Biofortification of Vegetables Could Improve Iodine Supplementation Status
}

\author{
Eva Duborská ${ }^{1, *}$, Martin Urík $^{1}$ and Martin Šeda ${ }^{2} \mathbb{B}$ \\ 1 Institute of Laboratory Research on Geomaterials, Faculty of Natural Sciences, Comenius University in \\ Bratislava, Mlynská dolina, Ilkovičova 6, 84215 Bratislava, Slovak Republic; martin.urik@uniba.sk \\ 2 Department of Applied Chemistry, Faculty of Agriculture, University of South Bohemia, Studentská 1668, \\ 37005 České Budějovice, Czech Republic; m_seda@centrum.cz \\ * Correspondence: duborska.eva@gmail.com or ugeol@fns.uniba.sk; Tel.: +421-(02)-602-96-392
}

Received: 17 September 2020; Accepted: 6 October 2020; Published: 15 October 2020

\begin{abstract}
Iodine is an essential trace element for both humans and animals. It is essential to produce important hormones by the thyroid gland. In most inland areas, the soils are iodine deficient and its amount is insufficient to produce agricultural crops with adequate iodine content to cover the recommended daily intake. In connection with the occurrence of iodine deficiency disorders (IDDs), it has been the subject of intensive research in the past. However, following the introduction of iodized table salt in the food industry, problems related to IDD were not solved and studies on iodine mobility and bioavailability from soils are rare even today and have remained insufficiently investigated. In many countries, mainly in Europe, the prescription rate of medicaments used to treat goiter is still high. Thus, there are a considerable amount of studies looking for alternative methods for iodine supplementation in foodstuffs among the use of iodized table salt. In most cases, the subject of these studies are agricultural crops. This mini review presents the consequences of inadequate and excess iodine intake, the current status of iodine supplementation and the most recent alternative methods of the application of iodine in agriculture and its effect on the quality of used plant species.
\end{abstract}

Keywords: iodine; biofortification; nutrition; vegetables; iodine deficiency

\section{Introduction}

Iodine is an essential micronutrient in humans, and although its deficiency-related disorders were a serious problem in the past, they still persist in some areas and have an endemic character. In the 1920s, the US [1] and Switzerland [2] were the first countries where table salt fortification with iodine began. Since the 1990s, several fortification programs were implemented and more than $70 \%$ of the world's population is estimated to be well supplied [3]. Still, the program seems to fail for several reasons in some other countries. Despite several existing methods battling iodine deficiency, this issue is still widespread, and it has reappeared in Australia and the UK. While in some countries only table salt is iodized, others also include iodine in salt for specific products (e.g., bread salt) [4]. A major goal is to fortify products in the food industry, but there is a misperception that the addition of fortified salt to processed food alters taste and color [5].

Rasmussen et al. [6] investigated through an 11-year follow-up study the effectiveness of the Danish iodine fortification program by evaluating urinary iodine excretion. They examined factors that could change iodine intake, such as dietary habits, education, lifestyle factors, and health parameters. Median urinary iodine concentration in the population had increased significantly during investigated years in all age and gender groups, but it was still below the recommended amount. The study showed that the increase in iodine excretion was positively associated with the usage of iodine supplements, the consumption of bread with iodine-fortified salt, and the higher milk intake, which is a natural 
source of iodine, thus, the iodine content there might be elevated due to cattle supplementation [7]. The strategy to combat iodine deficiency in Denmark seems to be working, however, the level of iodine fortification of salt is too low [6].

Charlton et al. [8] stated that mandatory fortification in Australia could be effective. However, there is inadequate knowledge about iodine requirements among the population. Overall knowledge regarding health implications of iodine deficiency was poor and dietary intake alone was insufficient to meet the increased needs of women during pregnancy. Only women taking iodine-containing supplements had adequate urinary iodine levels [8]. Since the mandatory salt iodization program in several countries started, the number of iodine-deficient countries in the world has decreased from 54 in 2003 to 32 in 2011. Surprisingly, 11 (34\%) of these countries are developed countries in Europe [9]. During the year 2013, the International Council for the Control of Iodine Deficiency Disorders (ICCIDD) performed a postal survey requesting information on the iodine status from the most affected areas in West and Central European regions. The results showed that at least 400 million people from 20 countries have no or limited access to iodized salt. Only 13 European countries responded that salt iodization is mandatory [4]. It is alarming that Europe has the most iodine-deficient countries from any continent [9]. This is a particularly important issue for iodine nutrition requirements during pregnancy and breastfeeding. In the past decade, the mild to moderate iodine deficiency in the first trimester of pregnancy among pregnant women in the UK was associated with a decrease in the intelligence quotient of offspring with a major negative impact on the verbal intelligence quotient [10]. Thyroid screening tests in Hungary among schoolchildren revealed that $21 \%$ of children had an enlarged thyroid gland, with significantly higher occurrence in boys $(24.9 \%)$ than in girls $(17.1 \%)$. Along with the occurrence of goiter, the median value of urinary iodide in half of the subjects showed a slight iodine deficiency [11]. The number of iodine-deficient countries worldwide divided into regions is listed in Table 1. The data clearly show that the current iodine supplementation is not sufficient, and the strategies for iodine status improvement worldwide should be changed. Insufficient or excessive iodine intake causes abortion, stillbirths, prenatal mortality, cretinism, goiter, endemic mental retardation, impaired mental function, hypo- and hyperthyroidism, autoimmune thyroid diseases, and increased susceptibility of the thyroid gland to nuclear radiation $[12,13]$. The recommended daily iodine intake for school-age children is listed in Table 2.

Table 1. Country data on median urinary iodine concentrations and urinary iodine concentrations in school-age children by region [13].

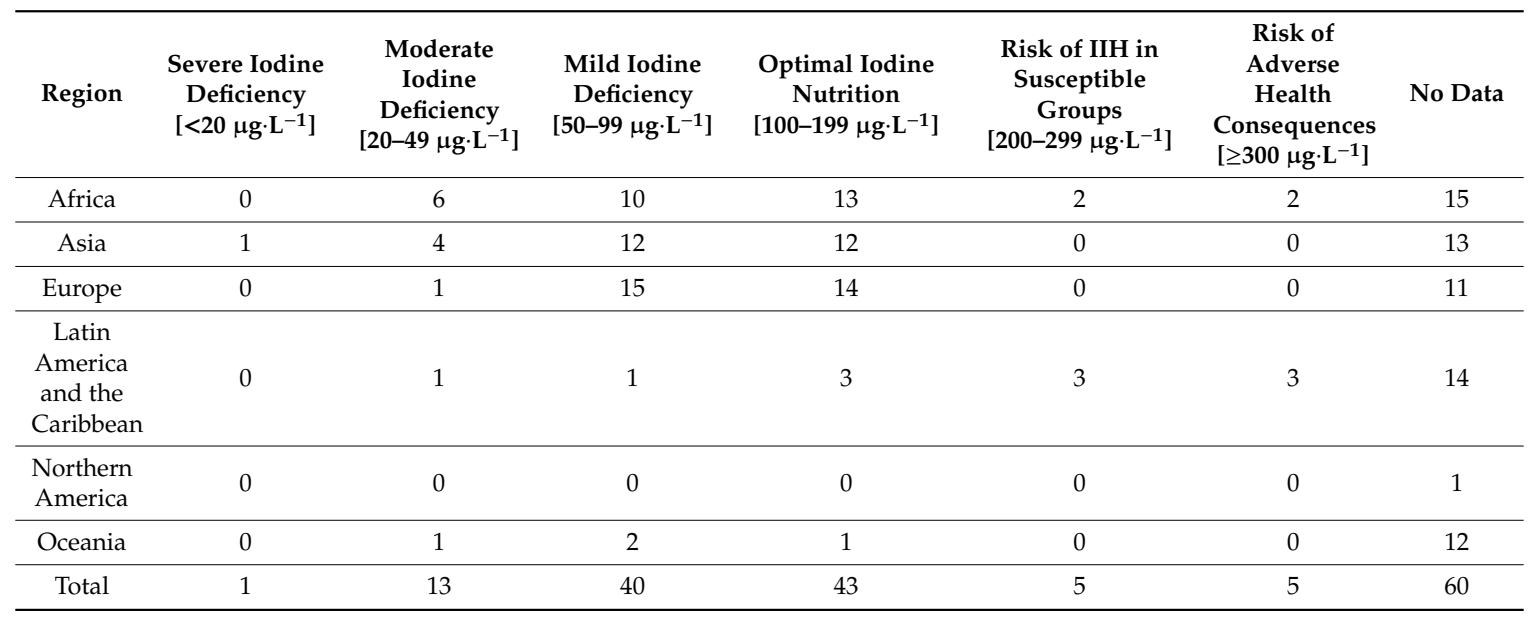


Table 2. Criteria for assessing adequate daily iodine intake based on median urinary iodine (UI) concentrations in school-age children [13].

\begin{tabular}{ccc}
\hline Median UI $\left[\boldsymbol{\mu} \mathbf{~ L}^{-\mathbf{1}}\right]$ & Iodine Intake & Nutrition \\
\hline$<20$ & Insufficient & Severe iodine deficiency \\
\hline 20201349 & Insufficient & Moderate iodine deficiency \\
\hline $50-99$ & Insufficient & Mild iodine deficiency \\
\hline $100-199$ & Adequate & Optimal iodine nutrition \\
\hline $200-299$ & More than adequate & $\begin{array}{c}\text { Risk of iodine-induced } \\
\text { hyperthyroidism in susceptible groups }\end{array}$ \\
\hline$>300$ & Excessive & Risk of adverse health consequences \\
\hline
\end{tabular}

\section{Iodine in Foodstuffs}

Table salt is the main target for iodine fortification in the human diet. According to the WHO [14], some assumptions must be taken into account for salt iodination strategy, such as iodine loss during storage and cooking. Almost $20 \%$ of iodine is lost during transport from production site to the household, and another $20 \%$ before consumption during the cooking process. Therefore, in order to provide a daily $150 \mu \mathrm{g}$ iodine intake via iodized salt, the initial iodine concentration in the salt at the point of production must be within the range of $20-40 \mathrm{mg} \cdot \mathrm{kg}^{-1}$. With this and iodine intake only from the iodized salt, the urinary iodine levels should be $100-200 \mu \mathrm{g} \cdot \mathrm{L}^{-1}[14]$.

In Europe, the permitted sources of iodine in table salt are $\mathrm{KI}, \mathrm{KIO}_{3}$, or $\mathrm{NaI}$. In some countries, bread and processed food fortification is also mandatory [15]. For example, the use of iodinated bread salt has been mandatory since 2000 in Denmark because these foods are consumed by nearly everyone. Since then, it has been legal to sell non-fortified bread and salt only if they are produced in another country [6]. The main source of iodine in the diet is seafood. However, in inland regions, where the source of iodine is external to soils [16], it is mostly milk and dairy products, meat, and to a lesser extent, plants.

As indicated, cooking processes can affect the quantity of iodine in food due to its volatile nature. Goindi et al. [17] evaluated iodine loss during several different cooking procedures through several traditional recipes. They found out that the mean losses of iodine during the different procedures used, in descending order, were boiling (37\%), shallow frying (27\%), pressure cooking (22\%), deep frying $(20 \%)$, steaming $(20 \%)$, and roasting (6\%) [17]. However, Meinhardt et al. [18] did not observe significant iodine loss during cooking when using salt fortified with $\mathrm{KIO}_{3}$ and concluded that waxy potatoes cut into small pieces and egg pasta showed the highest iodine uptake potential during cooking. The daily intake should not be much more than the recommended daily intake or maximum permitted level to prevent consequences of excessive intake [19]. The main sources of iodine in foodstuffs are presented in Table 3.

Table 3. Iodine content is selected foodstuffs.

\begin{tabular}{ccc}
\hline Food & Iodine Concentration & Source \\
\hline Milk & $242 \mathrm{mg} \cdot \mathrm{kg}^{-1}$ & {$[19]$} \\
Yogurt & $266 \mathrm{mg} \cdot \mathrm{kg}^{-1}$ & {$[19]$} \\
Cottage cheese & $490 \mathrm{mg} \cdot \mathrm{kg}^{-1}$ & {$[19]$} \\
Cheese & $265 \mathrm{mg} \cdot \mathrm{kg}^{-1}$ & {$[19]$} \\
Poultry meat & $130 \mathrm{mg} \cdot \mathrm{kg}^{-1}$ & {$[19]$} \\
Beef meat & $113 \mathrm{mg} \cdot \mathrm{kg}^{-1}$ & {$[19]$} \\
Fish & $315 \mathrm{mg} \cdot \mathrm{kg}^{-1}$ & {$[19]$} \\
Eggs & $50-100 \mathrm{mg} \cdot \mathrm{kg}^{-1}$ & {$[20]$} \\
Bread & $2.2-584 \mu \mathrm{gg} \mathrm{per} \mathrm{slice}$ & {$[21]$} \\
Processed meat products & $50-400 \mathrm{mg} \cdot \mathrm{kg}^{-1}$ & {$[19]$} \\
\hline
\end{tabular}




\section{Risk of Iodine-Induced Hyperthyroidism}

Iodine-induced hyperthyroidism is related to the rapidity of the increase in iodine intake and occurs in populations that already have severe iodine deficiency. It usually disappears in due course with the correction of the iodine deficiency, and it appears in patients who have pre-existing autonomous nodular goiter and in subjects with latent Graves' disease [14]. The main substances which induce excessive iodine intake are listed in Table 4. To prevent iodine-induced hyperthyroidism, an adequate iodine intake for normal thyroid function is required [22], and kelp supplements containing more than $500 \mu \mathrm{g}$ iodine should not be taken daily by patients with an iodine deficit [23]. Even the use of iodized salt can result in hyperthyroidism in deficient areas, probably from autoimmune origin [24]. Several iodine supplements, including iodinated contrast agents used for radiologic studies, contain iodine in much higher (several thousand-fold) concentrations than the recommended maximum daily intake. In susceptible individuals, these supplements can cause thyroid dysfunction after a single exposure, such as in patients with specific risk factors, including those with pre-existing thyroid disease among the elderly, fetuses, and neonates [25].

Table 4. Sources of excess iodine intake with potential thyroid disfunction risk.

\begin{tabular}{ccc}
\hline Supplement/Food & Amount of Iodine & Source \\
\hline Kelp & $16-8165 \mu \mathrm{g} \cdot \mathrm{g}^{-1}$ & {$[25]$} \\
Prenatal vitamins & Non-prescription $11-610$ per daily serving & {$[26,27]$} \\
Iodinated contrast & Prescription $26-220 \mu \mathrm{g}$ per daily serving & {$[24]$} \\
Saturated solution of potassium iodide & $13,500 \mu \mathrm{g}$ per CT scan & {$[24]$} \\
\hline
\end{tabular}

\section{Iodine Biofortification in Plants}

Plant iodine content is generally low, but still considered as an important source of dietary iodine for humans and grazing livestock [28]. Generally, iodine is toxic to plants but can be beneficial at low concentrations $[29,30]$. Its detrimental effects to specific plants depend on applied iodine species, mechanism of its uptake and transport by the plant, the sensitivity of the exposed organism and the mechanism of resistance, application method, and the properties of the used substrate [31]. The most effective method is foliar application for leafy vegetables [32].

Tonacchera et al. [33] proved that the consumption of biofortified vegetables mildly, but significantly, elevates urinary iodine concentration. The first successful in situ experiment on iodine biofortification was conducted by Jiang et al. [34]. Approximately 37,000 people were treated during this experiment. Potassium iodate was dripped into irrigation water on tilled land for four years. At the end of the experiment, the concentration of water-soluble iodine in the soil was three-fold higher than the concentration in the irrigation water, which declined subsequently with a half-life of two to four months, and declined to the level of neighboring non-treated soil iodine concentrations two years after the last dripping. Besides the increase in water-soluble soil iodine concentration, the uptake of iodine by plants (wheat, cabbage, maize, etc.) increased and persisted through three growing seasons. The thyroidal concentration of iodine increased three-fold in crop-fed chickens and sheep, but the increase was also observed in meat, eggs, and milk. Urinary iodine had increased significantly in all age groups and infant mortality decreased by $50 \%$ [34]. A similar study was conducted by the same authors a few years before this extensive field experiment with similarly positive results, thus, this method is considered as a cost-effective method of supplying iodine in areas dependent on irrigation [35]. Ren et al. [36] also used irrigation water treated with potassium iodate to soil fortification where, after a single application, soil iodine content increased two-fold and was available for more than four years after application.

Various studies proved that tomato is a suitable target plant for iodine biofortification and it can accumulate up to $10 \mathrm{mg}$ of iodine per $\mathrm{kg}$ of tomato fresh weight [37] Iodide and iodate, having no serious detrimental effects on plant growth and development or fruit yield, were shown to be suitable for tomato biofortification, covering the recommended daily intake [38]. Mild phytotoxic symptoms 
were observed, including leaf chlorosis, wilting, and epinasty. However, probably due to sorption phenomena, the organic matter-rich soil alleviated the adverse effects, while only a mild reduction of accumulated iodine in fruits was observed [37]. The addition of exogenous humic acids, which are great iodine sorbents [39] and, thus, play a main role in its soil retention, also prevents the deleterious effects of iodine on plants [40,41]. Furthermore, biofortification did not affect the quality of tomato, and storage had no effect on the iodine content in biofortified tomato fruit. Surprisingly, boiling did not affect the iodine content, while peeling lowered its content in fruits, as the peel alone contained a significant amount of iodine [37]. Usually, fruit contains the least iodine, as its concentration in plants usually follows the sequence roots $>$ leaves $>$ stems $>$ fruits [42].

Besides tomato, Li et al. [43] suggested that strawberries are also a suitable target for biofortification, with an accumulation of iodine up to $4000 \mu \mathrm{g} \cdot \mathrm{kg}^{-1}$ of fresh weight. Therefore, one serving of the biofortified strawberries can easily cover the daily recommended intake $\left(150 \mu \mathrm{g} \cdot \mathrm{day}^{-1}\right)$. Potassium iodide treatment also had several positive effects on the fruit quality of strawberry, such as increased biomass per plant and increased vitamin $C$ and soluble sugar contents, however, the high concentrations had detrimental effects on plant growth [43].

Biofortification was also successfully implemented on the fruit of pepper plants, which accumulated up to $1330 \mu \mathrm{g} \cdot \mathrm{kg}^{-1}$ from iodide solution during hydroponic experiments. In addition, some qualitative parameters such as ascorbic acid and soluble sugar contents increased slightly when the maximum iodine content of the solution did not exceed $1 \mathrm{mg} \cdot \mathrm{L}^{-1}$. Additionally, positive changes in photosynthetic activity in leaves and antioxidant capacity were observed. This enhanced the tolerance of pepper to elevated concentrations of exogenous iodine [42].

Irrigation water supplemented with iodine was also applied on rice. However, the accumulation rate of iodine by the grain was not sufficient, thus, the authors suggested that feeding farm animals with straw residues to enhance iodine content in meat and milk is a more plausible strategy [44]. Among other crops, carrots and lettuce are also good targets for iodine biofortification, as highlighted in Table 5. Generally, leafy vegetables are more convenient for dietary iodine intake because they are consumed raw, thus, the loss during cooking is eliminated and are easy to fortify via foliar application [41,45-47].

Table 5. List of studies on iodine biofortification of crops and the respective bioaccumulation efficiency related to the recommended daily intake per $100 \mathrm{~g}$ of fresh weight.

\begin{tabular}{|c|c|c|c|c|c|c|}
\hline Crop & Iodine Dosage & $\begin{array}{l}\text { Applied Iodine } \\
\text { Form }\end{array}$ & $\begin{array}{c}\text { Type of } \\
\text { Application }\end{array}$ & $\begin{array}{l}\text { Iodine Content } \\
\text { Per } 100 \mathrm{~g} \text { of Fresh } \\
\text { Weight }(\mu \mathrm{g})\end{array}$ & $\begin{array}{c}\% \text { of RDI } \\
\text { (Recommended } \\
\text { Daily Intake) }\end{array}$ & Source \\
\hline Carrot & $10-150 \mathrm{mg} \cdot \mathrm{kg}^{-1}$ & KI & Soil pot & $0-5000$ & $0-3333$ & [48] \\
\hline Celery & $10-150 \mathrm{mg} \cdot \mathrm{kg}^{-1}$ & KI & Soil pot & $500-16,000$ & $333-10,667$ & [49] \\
\hline Cucumber & $12-150 \mathrm{mg} \cdot \mathrm{m}^{-2}$ & Kelp fertilizer & Soil & $30-120$ & 20-80 & [50] \\
\hline Lettuce & $0.5-2 \mathrm{~kg} \cdot \mathrm{ha}^{-1}$ & $\mathrm{KIO}_{3}$ & Foliar application & $45-300$ & $30-200$ & [51] \\
\hline Pepper & $10-150 \mathrm{mg} \cdot \mathrm{kg}^{-1}$ & $\mathrm{KI}$ & Soil pot & $100-500$ & $67-333$ & [49] \\
\hline Potato & $0.05-0.5 \%$ & $\mathrm{KIO}_{3}$ & Irrigation water & $1870-3400$ & $1247-2267$ & [52] \\
\hline Radish & $10-150 \mathrm{mg} \cdot \mathrm{kg}^{-1}$ & Kelp fertilizer & Soil pot & $100-1300$ & $67-867$ & [53] \\
\hline Strawberry & $0.25-5 \mathrm{mg} \cdot \mathrm{L}^{-1}$ & $\mathrm{KI}, \mathrm{KIO}_{3}$ & Hydroponic & $400-4133$ & $400-2755$ & [43] \\
\hline Spinach & $0.5-2 \mathrm{mg} \cdot \mathrm{kg}^{-1}$ & $\mathrm{KIO}_{3}$ & Soil pot & $6-824$ & $4-549$ & [54] \\
\hline Tomato & $12-64 \mathrm{mg} \cdot \mathrm{dm}^{-3}$ & $\mathrm{KI}$ & Soil pot & 200-1000 & $133-667$ & [37] \\
\hline
\end{tabular}

\section{Influence of Soil and Agronomic Factors on Iodine Biofortification}

Iodine biofortification can be applied by addition of its dominant inorganic species, iodide and iodate, to water solutions, irrigation water, or soil. Except for these inorganic species, iodine-rich seaweed-based fertilizers were also successfully used for iodine biofortification $[48,49,55]$. Still, the foliar application of water solutions is the easiest way to biofortify crops with iodine. This method is most efficient when applied to leafy vegetables [51]. It was successfully tested on lettuce [51], fruit trees [56], kohlrabi [51], potato, carrot, and onion [57]. Iodine biofortification via hydroponic solutions also provided promising outcomes that were reported for spinach [58,59], 
lettuce [45], strawberry [43], tomato [60], and pepper [42]. In all cases, the bioaccumulation efficiency of iodine from hydroponic solutions was superior to other exposure methods. Still, the biofortification strategies from soils can be more beneficial due to the soil buffer ability driven by the interactions between iodine species and soil components, which alleviate the iodine toxic effects. The presence of humic acids in growth solutions can reduce the deleterious effects of iodine on plants by preventing its rapid and extensive uptake due to sorptive mechanisms which, on the other hand, can prevent the high accumulation rate of iodine in the plant tissues [40].

In soils, the application of iodate is more favorable than fortification using iodide. The uptake of iodate from soils was shown to be more successful by several studies, probably due to its slower uptake by plants [31]. Iodate is not as readily bioavailable as iodide, but probably has to be reduced to iodide prior to its uptake. This is very likely biologically mediated by roots or microbially in the rhizosphere [61]. Alternatively, interaction with humic substances can also lead to iodate reduction due to the presence of free redox active groups in their structure [62].

Still, iodide exposure was shown to have various adverse effects on plants. Lawson et al. [51] reported a $20 \%$ decrease in crop yield for lettuce and kohlrabi and common toxicity symptoms such as chlorosis and necrotic spots on the leaves, which were observed in the presence of iodine. However, at low concentrations, iodine can act as a growth enhancer and positively affect some quantitative and nutritional parameters of crops, which are important from an agricultural point of view and can make iodine biofortification attractive for farmers. Iodine increased the levels of glucose, fructose, and total sugar in edible parts of carrot [46] and tomato [63]. It enhanced antioxidant levels in leaves of lettuce [45], improved its response to salinity stress [64], increased the ascorbic acid content in edible parts of pepper, lettuce, barbary fig, and tomato $[42,63,65,66]$, and decreased levels of ammonium and lead accumulation in spinach, while the overall accumulation of nitrates and chlorides increased [67].

\section{Simultaneous Biofortification with Selenium Could Improve Global Thyroid Status}

In cases when the soil environment is deficient in more micronutrients that govern similar biological processes, plant biofortification with various micronutrients is an advantageous strategy. This is the case of iodine and selenium; and while iodine is needed as the constituent of thyroid hormones (triiodothyronine and tetraiodothyronine), selenium is also essential for the biosynthesis and function of a small number of selenocysteine-containing selenoproteins implicated in thyroid hormone metabolism and gland function. Selenium also has a role in the prevention of autoimmune thyroid diseases in women of childbearing age [68]. Several studies confirmed that patients treated with $200 \mu \mathrm{g}$ of selenium had improved patient thyroid condition. It decreased the amount of thyroid peroxidase (TPO) antibodies in patients with autoimmune thyroiditis and Hashimoto's thyroiditis [69] and decreased the incidence of postpartum thyroiditis in women positively tested for TPO antibodies [70].

Rasmussen et al. [71] investigated the association between blood serum selenium concentration, thyroid volume, and risk of an enlarged thyroid gland in an area where mild iodine deficiency was eliminated after introducing iodine fortification. They found that low serum selenium concentration was associated with a larger thyroid volume and a higher prevalence of thyroid enlargement [71]. A similar study was conducted in Ethiopia in children with selenium deficiency. They also found that serum selenium is negatively associated with tetraiodothyronine hormone level in children and concluded that selenium deficiency in the area may endanger the effectiveness of the salt iodization program [72]. To improve thyroid status, selenium could also be biofortified along with iodine. There have only been a few attempts at the simultaneous biofortification of iodine and selenium. Smolen et al. [73] presented that the application of salicylic acid improves the efficiency of the uptake of both elements by lettuce. Despite the fact that selenium is not essential for plants, similarly to iodine, it has a positive impact on plant development and production parameters, such as increased seed production in canola [74]. Therefore, the simultaneous biofortification of iodine and selenium could be attractive to farmers if enough information is available to work out a proper biofortification strategy [75]. 
However, an extensive field research is still needed to establish the most optimal conditions for such an approach.

\section{Conclusions}

The elimination of iodine deficiency and iodine supplementation are still serious health issues, mainly in European countries. The daily intake should be adequate according to the recommended daily intake and the consumption of supplements and vitamins is not recommended to avoid adverse effects of excess iodine intake. In the right chemical form and application, iodine biofortification of crops is an attractive and cost-effective alternative approach to increase daily intake of iodine in order to eliminate iodine deficiency disorders. Plants such as lettuce, tomato, strawberries, potato, carrots, radish, and cucumber are good targets for iodine fortification, which could be simultaneously fortified with selenium in order to provide better support for thyroid health, as both elements are important for the healthy function of the thyroid gland. With more studies that are persuasive towards the public, the iodine biofortification of crops shows promising results, and together with the use of iodinated salt, it may significantly improve iodinedaily intake by humans without the risk of excessive iodine intake.

Author Contributions: E.D. wrote the study design and wrote the protocol. E.D., M.U., and M.Š. ran the search and reviewed the initial literature. E.D. manually reviewed all manuscripts for final inclusion. All authors contributed to the writing and final draft preparation of the manuscript. All authors have read and agreed to the published version of the manuscript.

Funding: This work has been financially supported by Scientific Grant Agency of the Ministry of Education of the Slovak Republic and the Slovak Academy of Sciences under the contracts VEGA Nos. 1/0146/18.

Conflicts of Interest: The authors declare no conflict of interest.

\section{References}

1. Leung, A.M.; Braverman, L.E.; Pearce, E.N. History of U.S. Iodine Fortification and Supplementation. Nutrition 2012, 4, 1740-1746. [CrossRef] [PubMed]

2. Bürgi, H.; Supersaxo, Z.; Selz, B. Iodine deficiency diseases in Switzerland one hundred years after Theodor Kocher's survey: A historical review with some new goitre prevalence data. Eur. J. Endocrinol. 1990, 123, 577-590. [CrossRef] [PubMed]

3. Andersson, M.; Karumbunathan, V.; Zimmermann, M.B. Global Iodine Status in 2011 and Trends over the Past Decade. J. Nutr. 2012, 142, 744-750. [CrossRef] [PubMed]

4. Lazarus, J.H. Iodine Status in Europe in 2014. Eur. Thyroid. J. 2014, 3, 3-6. [CrossRef] [PubMed]

5. Charlton, K.; Skeaff, S. Iodine fortification: Why, when, what, how, and who? Curr. Opin. Clin. Nutr. Metab. Care 2011, 14, 618-624. [CrossRef]

6. Rasmussen, L.B.; Jørgensen, T.; Perrild, H.; Knudsen, N.; Krejbjerg, A.; Laurberg, P.; Pedersen, I.B.; Bjergved, L.; Ovesen, L. Mandatory iodine fortification of bread and salt increases iodine excretion in adults in Denmark-A 11-year follow-up study. Clin. Nutr. 2014, 33, 1033-1040. [CrossRef]

7. Franke, K.; Meyer, U.; Wagner, H.; Flachowsky, G. Influence of various iodine supplementation levels and two different iodine species on the iodine content of the milk of cows fed rapeseed meal or distillers dried grains with solubles as the protein source. J. Dairy Sci. 2009, 92, 4514-4523. [CrossRef]

8. Charlton, K.; Yeatman, H.; Lucas, C.J.; Axford, S.; Gemming, L.; Houweling, F.; Goodfellow, A.; Ma, G. Poor Knowledge and Practices Related to Iodine Nutrition during Pregnancy and Lactation in Australian Women: Pre- and Post-Iodine Fortification. Nutrition 2012, 4, 1317-1327. [CrossRef]

9. Zimmermann, M.B.; Andersson, M. Update on iodine status worldwide. Curr. Opin. Endocrinol. Diabetes Obes. 2012, 19, 382-387. [CrossRef]

10. Bath, S.C.; Walter, A.; Taylor, A.; Wright, J.; Rayman, M.P. Iodine deficiency in pregnant women living in the South East of the UK: The influence of diet and nutritional supplements on iodine status. Br. J. Nutr. 2014, 111, 1622-1631. [CrossRef]

11. Solymosi, T.; Farkas, I. 2032 iskoláskorú gyermek pajzsmirigy-ultrahangvizsgálatából levonható néhány tanulság: A jódellátottság és az attól független tényezők szerepe a golyva kialakulásában. Gyermekgyógyászat $2003,54,55-62$. 
12. Hetzel, B.S. Iodine and neuropsychological development. J. Nutr. 2000, 130, 493S-495S. [CrossRef] [PubMed]

13. Zimmermann, M.B.; Jooste, P.L.; Pandav, C.S. Iodine-deficiency disorders. Lancet 2008, 372, 1251-1262. [CrossRef]

14. WHO. Recommended Iodine Levels in Salt and Guidelines for Monitoring Their Adequacy and Effectiveness; World Health Organization: Geneva, Switzerland, 1996; p. 12.

15. European Commision. Discussion Paper on the Setting of Maximum and Minimum Amounts for Vitamins and Minerals in Foodstuffs; Health and Consumer Protection Directorate-General European Communities: Brussels, Belgium, 2006.

16. Šeda, M.; Švehla, J.; Trávniček, J.; Kroupová, V.; Konečný, R.; Fiala, K.; Svozilová, M.; Krhovjaková, J. The effect of volcanic activity of the Eyjafjallajökul volcano on iodine concentration in precipitation in the Czech Republic. Geochem. 2012, 72, 279-281. [CrossRef]

17. Goindi, G.; Karmarkar, M.G.; Kapil, U.; Jagannathan, J. Estimation of losses of iodine during different cooking procedures. Asia Pac. J. Clin. Nutr. 1995, 4, 225-227. [PubMed]

18. Meinhardt, A.-K.; Müller, A.; Burcza, A.; Greiner, R. Influence of cooking on the iodine content in potatoes, pasta and rice using iodized salt. Food Chem. 2019, 301, 125293. [CrossRef] [PubMed]

19. WHO. Guideline: Fortification of Food-Grade Salt with Iodine for the Prevention and Control of Iodine Deficiency Disorders; World Health Organisation: Geneva, Switzerland, 2014; p. 44.

20. Hejtmánková, A.; Vejdová, M.; Trnková, E. Stanovení jodu v biologickém materiálu metodou HPLC s elektrochemickým detektorem. Chemické Listy. 2005, 99, 657-660.

21. Dahl, L.; Opsahl, J.A.; Meltzer, H.M.; Julshamn, K. Iodine concentration in Norwegian milk and dairy products. Br. J. Nutr. 2003, 90, 679-685. [CrossRef]

22. Pearce, E.N.; Pino, S.; He, X.; Bazrafshan, H.R.; Lee, S.L.; Braverman, L.E. Sources of Dietary Iodine: Bread, Cows' Milk, and Infant Formula in the Boston Area. J. Clin. Endocrinol. Metab. 2004, 89, 3421-3424. [CrossRef]

23. Leung, A.M.; Avram, A.M.; Brenner, A.V.; Duntas, L.H.; Ehrenkranz, J.; Hennessey, J.V.; Lee, S.L.; Pearce, E.N.; Roman, S.A.; Stagnaro-Green, A.; et al. Potential Risks of Excess Iodine Ingestion and Exposure: Statement by the American Thyroid Association Public Health Committee. Thyroid 2015, 25, 145-146. [CrossRef]

24. Pedersen, I.B.; Laurberg, P.; Knudsen, N.; Jørgensen, T.; Perrild, H.; Ovesen, L.; Rasmussen, L.B. Increase in Incidence of Hyperthyroidism Predominantly Occurs in Young People after Iodine Fortification of Salt in Denmark. J. Clin. Endocrinol. Metab. 2006, 91, 3830-3834. [CrossRef] [PubMed]

25. Leung, A.M.; Braverman, L.E. Consequences of excess iodine. Nat. Rev. Endocrinol. 2013, 10, $136-142$. [CrossRef] [PubMed]

26. Teas, J.; Pino, S.; Critchley, A.; Braverman, L.E. Variability of iodine content in common commercially available edible seaweeds. Thyroid 2004, 14, 836-841. [CrossRef]

27. Leung, A.M.; Pearce, E.N.; Braverman, L.E. Iodine Content of Prenatal Multivitamins in the United States. New Engl. J. Med. 2009, 360, 939-940. [CrossRef] [PubMed]

28. Lidiard, H. Iodine in the reclaimed upland soils of a farm in the Exmoor National Park, Devon, U.K. and its impact on livestock health. Appl. Geochem. 1995, 10, 85-95. [CrossRef]

29. Umaly, R.C.; Poel, L.W. Effects of Various Concentrations of Iodine as Potassium Iodide on the Growth of Barley, Tomato and Pea in Nutrient Solution Culture. Ann. Bot. 1970, 34, 919-926. [CrossRef]

30. Duborská, E.; Urík, M.; Kubová, J. Interaction with soil enhances the toxic effect of iodide and iodate on barley (Hordeum vulgare L.) compared to artificial culture media during initial growth stage. Arch. Agron. Soil Sci. 2017, 64, 46-57. [CrossRef]

31. Duborská, E.; Urík, M.; Bujdoš, M.; Kubová, J. Aging and Substrate Type Effects on Iodide and Iodate Accumulation by Barley (Hordeum vulgare L.). Water Air Soil Pollut. 2016, 227, 407. [CrossRef]

32. Cakmak, I.; Prom-U-Thai, C.; Guilherme, L.R.G.; Rashid, A.; Hora, K.H.; Yazici, A.; Savasli, E.; Kalayci, M.; Tutus, Y.; Phuphong, P.; et al. Iodine biofortification of wheat, rice and maize through fertilizer strategy. Plant Soil 2017, 418, 319-335. [CrossRef]

33. Tonacchera, M.; Dimida, A.; De Servi, M.; Frigeri, M.; Ferrarini, E.; De Marco, G.; Grasso, L.; Agretti, P.; Piaggi, P.; Aghini-Lombardi, F.; et al. Iodine Fortification of Vegetables Improves Human Iodine Nutrition: In Vivo Evidence for a New Model of Iodine Prophylaxis. J. Clin. Endocrinol. Metab. 2013, 98, E694-E697. [CrossRef] 
34. Jiang, X.M.; Cao, X.Y.; Jiang, J.Y.; Tai, M.; James, D.W.; Rakeman, M.A.; Zhi-Hong, D.; Mamette, M.; Amette, K.; Ming-Li, Z.; et al. Dynamics of Environmental Supplementation of Iodine: Four Years' Experience of Iodination of Irrigation Water in Hotien, Xinjiang, China. Arch. Environ. Heal. Int. J. 1997, 52, $399-408$. [CrossRef] [PubMed]

35. Cao, X.-Y.; Jiang, X.-M.; Kareem, A.; Dou, Z.-H.; Rakeman, M.; Zhang, M.L.; Ma, T.; O’Donnell, K.; Delong, N.; Delong, G. Iodination of irrigation water as a method of supplying iodine to a severely iodine-deficient population in XinJiang, China. Lancet 1994, 344, 107-110. [CrossRef]

36. Ren, Q.; Fan, J.; Zhang, Z.; Zheng, X.; Delong, G.R. An environmental approach to correcting iodine deficiency: Supplementing iodine in soil by iodination of irrigation water in remote areas. J. Trace Elements Med. Biol. 2008, 22, 1-8. [CrossRef] [PubMed]

37. Kiferle, C.; Gonzali, S.; Holwerda, H.T.; Ibaceta, R.R.; Perata, P. Tomato fruits: A good target for iodine biofortification. Front. Plant Sci. 2013, 4. [CrossRef] [PubMed]

38. WHO. Iodine Status Worldwide: WHO Global Database on Iodine Deficiency; WHO: Geneva, Switzerland, 2004. [CrossRef]

39. Duborská, E.; Urík, M.; Bujdoš, M.; Matulová, M. Influence of physicochemical properties of various soil types on iodide and iodate sorption. Chemosphere 2019, 214, 168-175. [CrossRef]

40. Mackowiak, C.L.; Grossl, P.R.; Cook, K. Iodine toxicity in a plant-solution system with and without humic acid. Plant Soil 2005, 269, 141-150. [CrossRef]

41. Smoleń, S.; Ledwożyw-Smoleń, I.; Sady, W. The role of exogenous humic and fulvic acids in iodine biofortification in spinach (Spinacia oleracea L.). Plant Soil 2015, 402, 129-143. [CrossRef]

42. Li, R.; Li, D.-W.; Liu, H.-P.; Hong, C.-L.; Song, M.-Y.; Dai, Z.-X.; Liu, J.-W.; Zhou, J.; Weng, H. Enhancing iodine content and fruit quality of pepper ( Capsicum annuum L.) through biofortification. Sci. Hortic. 2017, 214, 165-173. [CrossRef]

43. Li, R.; Liu, H.-P.; Hong, C.-L.; Dai, Z.-X.; Liu, J.-W.; Zhou, J.; Hu, C.-Q.; Weng, H.-X. Iodide and iodate effects on the growth and fruit quality of strawberry. J. Sci. Food Agric. 2016, 97, 230-235. [CrossRef]

44. Mackowiak, C.L.; Grossl, P.R. Iodate and iodide effects on iodine uptake and partitioning in rice (Oryza sativa L.) grown in solution culture. Plant Soil 1999, 212, 133-141. [CrossRef]

45. Blasco, B.; Rios, J.J.; Cervilla, L.; Ruiz, J.; Romero, L.; Sánchez-Rodrigez, E. Iodine biofortification and antioxidant capacity of lettuce: Potential benefits for cultivation and human health. Ann. Appl. Biol. 2008, 152, 289-299. [CrossRef]

46. Smoleń, S.; Sady, W.; Ledwożyw-Smoleń, I.; Strzetelski, P.; Liszka-Skoczylas, M.; Rożek, S. Quality of fresh and stored carrots depending on iodine and nitrogen fertilization. Food Chem. 2014, 159, 316-322. [CrossRef] [PubMed]

47. Voogt, W.; Holwerda, H.T.; Khodabaks, R. Biofortification of lettuce (Lactuca sativa L.) with iodine: The effect of iodine form and concentration in the nutrient solution on growth, development and iodine uptake of lettuce grown in water culture. J. Sci. Food Agric. 2010, 90, 906-913. [CrossRef] [PubMed]

48. Hong, C.-L.; Weng, H.; Qin, Y.-C.; Yan, A.-L.; Xie, L.-L. Transfer of iodine from soil to vegetables by applying exogenous iodine. Agron. Sustain. Dev. 2008, 28, 575-583. [CrossRef]

49. Hong, C.-L.; Weng, H.-X.; Yan, A.-L.; Islam, E.-U. The fate of exogenous iodine in pot soil cultivated with vegetables. Environ. Geochem. Heal. 2008, 31, 99-108. [CrossRef]

50. Weng, H.; Hong, C.; Xia, T.; Bao, L.; Liu, H.; Li, D. Iodine biofortification of vegetable plants-An innovative method for iodine supplementation. Chin. Sci. Bull. 2013, 58, 2066-2072. [CrossRef]

51. Lawson, P.G.; Daum, D.; Czauderna, R.; Meuser, H.; Härtling, J.W. Soil versus foliar iodine fertilization as a biofortification strategy for field-grown vegetables. Front. Plant Sci. 2015, 6. [CrossRef]

52. Caffagni, A.; Arru, L.; Meriggi, P.; Milc, J.; Perata, P.; Pecchioni, N. Iodine Fortification Plant Screening Process and Accumulation in Tomato Fruits and Potato Tubers. Commun. Soil Sci. Plant Anal. 2011, 42, 706-718. [CrossRef]

53. Weng, H.-X.; Weng, J.-K.; Yan, A.-L.; Hong, C.-L.; Yong, W.-B.; Qin, Y.-C. Increment of Iodine Content in Vegetable Plants by Applying Iodized Fertilizer and the Residual Characteristics of Iodine in Soil. Biol. Trace Element Res. 2008, 123, 218-228. [CrossRef]

54. Dai, J.; Zhu, Y.-G.; Huang, Y.Z.; Zhang, M.; Song, J.L. Availability of iodide and iodate to spinach (Spinacia oleracea L.) in relation to total iodine in soil solution. Plant Soil 2006, 289, 301-308. [CrossRef] 
55. Weng, H.-X.; Liu, H.-P.; Li, D.; Ye, M.; Pan, L.; Xia, T.-H. An innovative approach for iodine supplementation using iodine-rich phytogenic food. Environ. Geochem. Heal. 2014, 36, 815-828. [CrossRef] [PubMed]

56. Caffagni, A.; Pecchioni, N.; Meriggi, P.; Bucci, V.; Sabatini, E.; Acciarri, N.; Ciriaci, T.; Pulcini, L.; Felicioni, N.; Beretta, M.; et al. Iodine uptake and distribution in horticultural and fruit tree species. Ital. J. Agron. 2012, 7, 32. [CrossRef]

57. Zanirato, V.; Mayerle, M.; Pizzoli SpA. Method of Enriching Crops with Iodine and Crops thus Obtained. International Patent PCT/EP2009/050142, 1 July 2009.

58. Zhu, Y.-G.; Huang, Y.-Z.; Hu, Y.; Liu, Y.-X. Iodine uptake by spinach (Spinacia oleracea L.) plants grown in solution culture: Effects of iodine species and solution concentrations. Environ. Int. 2003, 29, 33-37. [CrossRef]

59. Weng, H.-X.; Yan, A.-L.; Hong, C.-L.; Xie, L.-L.; Qin, Y.-C.; Cheng, C.Q. Uptake of Different Species of Iodine by Water Spinach and Its Effect to Growth. Biol. Trace Element Res. 2008, 124, 184-194. [CrossRef] [PubMed]

60. Landini, M.; Gonzali, S.; Perata, P. Iodine biofortification in tomato. J. Plant Nutr. Soil Sci. 2011, 174, 480-486. [CrossRef]

61. Kato, S.; Wachi, T.; Yoshihira, K.; Nakagawa, T.; Ishikawa, A.; Takagi, D.; Tezuka, A.; Yoshida, H.; Yoshida, S.; Sekimoto, H.; et al. Rice (Oryza sativa L.) roots have iodate reduction activity in response to iodine. Front. Plant Sci. 2013, 4. [CrossRef]

62. Reiller, P.E.; Mercier-Bion, F.; Gimenez, N.; Barré, N.; Miserque, F. Iodination of humic acid samples from different origins. Radiochim. Acta 2006, 94, 739. [CrossRef]

63. Smoleń, S.; Wierzbińska, J.; Sady, W.; Kołton, A.; Wiszniewska, A.; Liszka-Skoczylas, M. Iodine biofortification with additional application of salicylic acid affects yield and selected parameters of chemical composition of tomato fruits (Solanum lycopersicum L.). Sci. Hortic. 2015, 188, 89-96. [CrossRef]

64. Leyva, R.; Sánchez-Rodríguez, E.; Ríos, J.J.; Rubio-Wilhelmi, M.M.; Romero, L.; Ruiz, J.M.; Blasco, B. Beneficial effects of exogenous iodine in lettuce plants subjected to salinity stress. Plant Sci. 2011, 181, 195-202. [CrossRef]

65. Blasco, B.; Rios, J.J.; Leyva, R.; Cervilla, L.M.; Sánchez-Rodríguez, E.; Rubio-Wilhelmi, M.M.; Rosales, M.A.; Ruiz, J.M.; Romero, L. Does Iodine Biofortification Affect Oxidative Metabolism in Lettuce Plants? Biol. Trace Element Res. 2010, 142, 831-842. [CrossRef]

66. Osuna, H.T.G.; Mendoza, A.B.; Morales, C.R.; Rubio, E.M.; Star, J.V.; Ruvalcaba, R.M. Iodine Application Increased Ascorbic Acid Content and Modified the Vascular Tissue in Opuntia Ficus-indica L. Pak. J. Botany 2014, 46, 127-134.

67. Smoleń, S.; Sady, W. Influence of iodine form and application method on the effectiveness of iodine biofortification, nitrogen metabolism as well as the content of mineral nutrients and heavy metals in spinach plants (Spinacia oleracea L.). Sci. Hortic. 2012, 143, 176-183. [CrossRef]

68. Schomburg, L.; Köhrle, J. On the importance of selenium and iodine metabolism for thyroid hormone biosynthesis and human health. Mol. Nutr. Food Res. 2008, 52, 1235-1246. [CrossRef] [PubMed]

69. Gärtner, R.; Gasnier, B.C.H.; Dietrich, J.W.; Krebs, B.; Angstwurm, M.W.A. Selenium Supplementation in Patients with Autoimmune Thyroiditis Decreases Thyroid Peroxidase Antibodies Concentrations. J. Clin. Endocrinol. Metab. 2002, 87, 1687-1691. [CrossRef] [PubMed]

70. Negro, R.; Greco, G.; Mangieri, T.; Pezzarossa, A.; Dazzi, D.; Hassan, H. The Influence of Selenium Supplementation on Postpartum Thyroid Status in Pregnant Women with Thyroid Peroxidase Autoantibodies. J. Clin. Endocrinol. Metab. 2007, 92, 1263-1268. [CrossRef] [PubMed]

71. Rasmussen, L.B.; Schomburg, L.; Köhrle, J.; Pedersen, I.B.; Hollenbach, B.; Hög, A.; Ovesen, L.; Perrild, H.; Laurberg, P. Selenium status, thyroid volume, and multiple nodule formation in an area with mild iodine deficiency. Eur. J. Endocrinol. 2011, 164, 585-590. [CrossRef] [PubMed]

72. Gashu, D.; Stoecker, B.J.; Adish, A.; Haki, G.D.; Bougma, K.; E Aboud, F.; Marquis, G.S. Association of serum selenium with thyroxin in severely iodine-deficient young children from the Amhara region of Ethiopia. Eur. J. Clin. Nutr. 2016, 70, 929-934. [CrossRef]

73. Smoleń, S.; Kowalska, I.; Czernicka, M.; Halka, M.; Kęska, K.; Sady, W. Iodine and Selenium Biofortification with Additional Application of Salicylic Acid Affects Yield, Selected Molecular Parameters and Chemical Composition of Lettuce Plants (Lactuca sativa L. var. capitata). Front. Plant Sci. 2016, 7, 1553. [CrossRef] 
74. Lyons, G.H.; Genc, Y.; Soole, K.L.; Stangoulis, J.C.R.; Liu, F.; Graham, R.D. Selenium increases seed production in Brassica. Plant Soil 2008, 318, 73-80. [CrossRef]

75. Lyons, G. Biofortification of Cereals with Foliar Selenium and Iodine Could Reduce Hypothyroidism. Front. Plant. Sci. 2018, 9. [CrossRef]

Publisher's Note: MDPI stays neutral with regard to jurisdictional claims in published maps and institutional affiliations.

(C) 2020 by the authors. Licensee MDPI, Basel, Switzerland. This article is an open access article distributed under the terms and conditions of the Creative Commons Attribution (CC BY) license (http://creativecommons.org/licenses/by/4.0/). 